\title{
THE CONTRACT CLAUSE AND SUPREME COURT DECISIONMAKING: A BICENTENNIAL RETROSPECTIVE ${ }^{1}$
}

\author{
Albert P. Melone \\ (Southern Illinois University at Carbondale)
}

\section{Introduction}

It is fitting that during the period of the bicentennial celebration of the U.S. Constitution public law scholars both reexamine constitutional history and engage in an introspective examination of the subfield within political science. There is dissatisfaction with the dominant approaches of political jurisprudence and judicial behavioralism (Stumpf 1983). Public choice theory, critical legal theory, and some normative models are vying for paradigmatic hegemony. Yet important figures of political jurisprudence and judicial behavioralism such as Pritchett, Murphy, Tanenhaus, Schubert, Schmidhauser, Nagel, Shapiro, and Ulmer, among others, have contributed greatly in explaining judicial decisionmaking in realistic political and human terms. It is a mistake to discard the advances of the last three or four decades in favor of approaches lacking explanatory power. Science, not rhetoric, must remain our epistemological foundation.

Rogers Smith (1988) offers a positive and prudent reconceptualization of the subfield. Borrowed from James March and Johan Olsen (1984) in a broader political context, the "new institutionalism" addresses what Theda Skocpol $(1984,4)$ terms the " dialectic of meaningful action and structural determinants." Smith urges us to view the Supreme Court as a relatively autonomous political and legal organization with a life of its own. We should inquire: does the institution produce its own expectations which influence decisionmaking independent of the deep economic and social structures and the social backgrounds of judicial actors?

It is possible and desirable to join the approaches of political jurisprudence and judicial behavioralism with the new institutionalism as well as the older textual approaches to create a better understanding of legal processes. In this article I analyze the various modes of constitutional interpretation employed by the Supreme Court in contract clause litigation beginning with John Marshall's tenure and ending with Warren Burger's era. It exemplifies how the interplay of law and politics, ideology, and 
modes of interpretation affect constitutional meaning. It also illustrates that political factors are mitigated by historical conditions, and institutional expectations. Though affected by social forces, the Supreme Court is not a mirror image of such factors. Influenced by powerful historical forces it also affects those forces.

\section{The Rise of the Contract Clause}

The period between the Revolutionary War and the Philadelphia Convention (1776-1787) was one which frightened important elements within American society. Whereas the War of Independence was fought to end monarchical despotism, the new perceived danger was the vice of liberty; the abuse of power may result in tyranny but perversion of liberty will yield licentiousness (Wood 1969, 409-413). One manifestation of the ostensible corruption of republican principles was the democratic sentiments of state legislators. Responding to the demands of their debt-ridden constituents, they enacted laws which tended to relieve debtors of their contractual obligations. The most pernicious of these statutes were those providing for the issuance of cheap paper currency, with the frequent requirement that such paper be accepted for the payment of debts. There were also stay laws, which postponed debt payment beyond the time stipulated in contractual agreements. Other state laws permitted installment payments over a period of months or years instead of the lump sum agreed to in the terms of the original contract. A popular form of debtor relief legislation was the commodity payment scheme. This legislative remedy permitted the payment of a debt by the transfer of certain commodities, usually as a proportion of their appraised value in lieu of monetary repayment.

Examining the records of the Constitutional Convention, one finds little specific evidence for the Framers' intention in writing the contract clause into the basic law (Farrand 1937). This is probably traceable to the Framers' preoccupation with the state practice of issuing paper money. With the constitutional prohibition against state issuance of money and the national government fully empowered to coin money and to regulate its value, state debtor relief legislation was effectively curbed (Wright 1938, 5-6). Also, the ex post facto prohibition may have been seen as an additional barrier to debtor relief laws. ${ }^{2}$ The contract clause may therefore be viewed as part of a constellation of provisions designed to cope with attacks of the debtor class upon property. No doubt the adoption of the two clauses, the paper money prohibition and the contract clause, must be 
viewed as an important political victory for significant elements within the socioeconomic elite of the day (Beard 1913, 179).

Notwithstanding the Framers' probable intent, the first important Supreme Court contract clause interpretation involved a legislative grant and not an agreement among private parties. The case of Fletcher v. Peck (10 U.S. 6 Cranch 87 [1810]) is an early illustration of corruption in American politics, the obvious interdependence of law and politics, and what is widely regarded as John Marshall's expansive reading of the Constitution.

Subjected to the most blatant bribery, the Georgia legislature sold much of which is now part of Mississippi. Thirty-five million acres of land was exchanged for a total of $\$ 500,000$. Outraged by the land giveaway, Georgians voted the incumbents out of office and a year later, in 1796, the new legislature passed a repeal law. Under the terms of this law, investors could have their money refunded. However, most investors refused to do so because a refund signified the abandonment of their legal claims. What is more important is that much of the Yazoo lands were quickly sold to third parties. One major purchaser, the New England Mississippi Land Company, then resold the land at a handsome profit to allegedly innocent third parties (Magrath 1966,1-19). After a bitter campaign spanning two decades, Congress was persuaded to bail out the land speculators. Under the terms of an 1802 Georgia-United States agreement, Yazoo lands were ceded to the United States and a five million acre tract was set aside to repay claimants if Congress decided to compensate them (Magrath, 1966, 35-36). Following years of rancorous debate and a subsequent Supreme Court decision, Congress in 1814 enacted a generous compensation law (Magrath 1966, 97).

Fletcher v. Peck was clearly part of a grand strategy to obtain compensation. By asserting that the 1796 Georgia repeal act was unconstitutional, the Yazooists indubitably strengthened their argument in Congress (Magrath, 1966, 93,95, 96-97, 112-113). As hinted by Associate Justice William Johnson in his concurring opinion (10 U.S. 6 Cranch 146 [1810]), there is little doubt that the case was collusive or feigned (Magrath 1966, 54-55). Moreover, casting doubt on whether it fit the constitutional requirement of an actual case or controversy, both parties to the suit stood to gain from a declaration of unconstitutionality. Because he was intoxicated during oral argument, one wonders whether counsel for Fletcher viewed the matter with adversary wariness. Chief Justice Marshall adjourned the proceedings until counsel, Luther Martin, could regain his sobriety (Magrath, 1966, 69). By contemporary standards, John Marshall should have disqualified himself from the case. As a congressman from 
Virginia, he voted in favor of Yazoo compensation (Magrath 1966, 34), and he had himself been similarly victimized by the Virginia legislature (Magrath 1966, 73-74). Yet corruption, collusive suits, and judicial indiscretion should not come as a shock. The Yazoo case is equally interesting as an example of interest group lobbying. Long before such notable twentieth century organizations as the National Association for the Advancement of Colored People or the American Civil Liberties Union were busily employing the courts to influence public policy, political actors were keenly aware of how to use the courts in the political process (Magrath 1966, 112-113).

John Marshall's opinion is significant for several reasons. Fletcher v. Peck is the first major decision to strike down a state law as inconsistent with the federal constitution and is the state analogue to Marbury v. Madison. In what was to become standard fare, Marshall first paid homage to the delicacy of the question but then expressed the Court's responsibility to declare the repeal act void.

Marshall then proceeded to find that public grants by a sovereign are subject to the same limitations as are contracts among private parties. This is a particularly startling conclusion because, if anything, the evidence is that the Framers intended to limit state interference with contracts among private parties and not between a state and private parties. After all, the framing of the Constitution took place during an era in which debtors successfully lobbied state legislatures to relieve them of private contracts. The violation of public contracts was not a live political issue. ${ }^{3}$

A final contribution of Fletcher v. Peck to contract clause adjudication did not come from the Chief Justice alone. In his concurring opinion, Associate Justice William Johnson declared, " . . . a state does not possess the power of revoking its own grants. But I do it on a general principle which will impose laws even on the Deity" ( 10 U.S. 6 Cranch 143). Hence, the natural law was invoked and the notion of vested property rights became firmly embedded in the constitutional consciousness.

From a historical perspective, Dartmouth College v. Woodward (17 U.S. 4 Wheaton 518 [1819]) should be regarded as a completion of what began in Fletcher v. Peck. The British crown granted a charter to the trustees of Dartmouth College in 1769. After the Revolution, in 1816, the New Hampshire Legislature amended the charter to provide effective state control over the institution. In the Georgia case, the Court gleaned from general principles that public grants from a state legislature are by nature contracts and therefore are not voidable by a succeeding legislature. With Dartmouth, Marshall similarly managed to transform a corporate charter 
granted by a recently defeated British crown into a contract and also concluded that New Hampshire could not impair the obligation of contract. The evidence is slim that the Framers intended to apply the contract clause either to public grants or to corporate charters (Melone 1988). Even during the first few decades following the Philadelphia Convention, justices found it easy to ignore the Framers' intentions when it suited their ideological purposes. Although the Fletcher and Dartmouth cases represented a high point in the natural law doctrine of vested property rights, they are also the judicial precedents which made it difficult for the states to use their powers to combat the growing influence of corporate enterprise at a time when the states were the principal guardians of community wellbeing (Schmidhauser 1958, 47).

In the same year as the Dartmouth decision, the Marshall Court held in Sturges v. Crowninshield (U.S. 4 Wheaton 122 [1819]) that, in the absence of congressional bankruptcy legislation, the states may enact such laws. Such state bankruptcy legislation, enacted after and not before the vesting of contractual obligations, would constitute an impairment of contract. This rule was strictly applied in the 1827 U.S. Supreme Court case of Ogden v. Saunders (U.S. 12 Wheaton 213). The 4-3 majority held that if a state bankruptcy law is in effect when a contract is consummated, the state bankruptcy provisions are implied in the contract and therefore must be considered part of the contractual agreement. This was the only constitutional case in his thirty-four year Court tenure for which John Marshall felt compelled to offer a dissenting opinion (Wright 1938, 50).

With the accession of Roger Taney and all but one Jacksonian Democrat to the Supreme Court, one might have expected that states' rights and democratic sentiments might curb the late John Marshall's broad interpretation of the contract clause. Surprisingly enough, with rare exceptions, Marshall's doctrines protecting vested property rights remained operative ( Wright 1938, 63). In fact, the Taney Court (1836-64) applied the contract clause more frequently and widely than ever before. This Court applied the clause to debtor-creditor relations, to state legislation taxing and regulating banks, and even to an agreement between the federal government and the states. By the end of Taney's tenure, the rights of property were even more secure than they were during the Marshall era (Wright 1938, 62-82). Note political jurisprudence or judicial behavioralism perspectives cannot explain satisfactorily what happened. Court personnel changed and major political forces favored state power over national authority. However, John Marshall's interpretation and view of contract clause matters became the institutional norm. 
It is for these reasons that the decision in Charles River Bridge Co. v. Warren Bridge Co.(36 U.S. 11 Peters 420 [1837]) must not be construed as a repudiation of Marshall. The Massachusetts legislature granted, in 1650, Harvard College the right to operate a ferry between Charlestown and Boston on the Charles River. In 1785, the state legislature incorporated a company to build a bridge over the Charles River, granting the company tolls and payment to Harvard College for seventy years. After this period, the bridge was to become the property of the state. Yet in 1828 , the legislature incorporated a different company to erect a bridge some 800 feet from the Charles River bridge. This new bridge, called the Warren bridge, was to charge tolls but was to be free of charge after a few years. Obviously, this could only result in the end of revenues for the Charles River Bridge Company. The Charles River Bridge Company asserted the grant to Warren Bridge Company was a state impairment of contract. However, Chief Justice Taney ruled because there was no express language in the Charles River Bridge charter to the contrary, the state was free to incorporate the competing Warren Bridge Company. He found that public grants or franchises must be strictly construed and nothing may be implied in the phraseology of the grant or contract. The Charles River Bridge decision tended to curb Marshall's expansive doctrines, particularly those found in the Dartmouth case. But the strict construction doctrine of Charles River Bridge did not represent a major departure from the previous tradition. Taney's decision stands for the proposition that only those rights explicitly spelled out in a corporate charter are protected by the contract clause. This conclusion is based upon an important stated assumption, that is, a state cannot be presumed to surrender its power to promote ". . . the happiness and prosperity of the community by which it is established." (36 U.S. 11 Peters 547). Taney was nonetheless prepared to treat corporate charters as contracts and was willing to strike down state legislation which might impair them. In Charles River Bridge, Taney simply accepted the common law principle against implied grants to monopolies (36 U.S. 11 Peters 420).

\section{Signs of Decline, 1880-1965}

After the Civil War until about the 1880 s, propertied interests continued to use the contract clause as its principal constitutional weapon. When municipalities, for example, attempted to repudiate their bonded indebtedness, the Supreme Court ruled against the cities in all but a few of the approximately two hundred cases coming before it. By the 1870 s and 
1880s, however, the Court began to limit its use. The Court refused to extend the contract clause as a limitation upon the federal government. It also permitted the states to change the terms of bond issues and to regulate the rates charged by railroads and other corporations (Magrath 1966, 107108).

Although reminiscent of Taney's community "happiness and prosperity," Chief Justice Waite's opinion in Stone v. Mississippi (101 U.S. 814 [1880]) was the most forceful and dramatic statement favoring the police power of the state to date. Although a lottery company had obtained a state charter issued upon valuable consideration, the state of Mississippi effectively destroyed the company through a constitutional amendment and an enforcing act outlawing lotteries. Upholding the rescinding statute, a unanimous Court struck a blow for the principle of state police power with Chief Justice Waite's famous two lines: "No legislature can bargain away the public health or the public morals. The people themselves cannot do it, much less their servants"' (101 U.S. 819 [1880]).

Proponents of vested property rights need not lament the Stone decision. From about 1895 until 1937 property found a constitutional refuge within the meaning of due process of law. Substantive due process became an even more powerful constitutional tool than the application of Marshall's contract clause. Because due process requirements apply to both the state governments and to the national government, and because due process is limitless in its inherent vagueness, principles of substantive faimess became the major constitutional vehicle for striking down social and economic regulations (Pritchett 1968, 668-678).

Home Building \& Loan Association v. Blaisdell (290 U.S. 398 [1934]),popularly known as the Minnesota Moratorium Case, represented a restatement of the meaning of the contract clause; it is an important precedent for the principle of state power over vested property rights. A legislative measure to deal with widespread mortgage failures resulting from the economic calamity of the Great Depression, the litigated Minnesota statute extended the period of redemption on farming and home foreclosures. Yet this statute was similar to the old stay laws of the postRevolutionary War era (Wright 1938,211 ) which may serve as justification for a judicial finding of unconstitutionality. The five-to-four U.S. Supreme Court majority needed a way to justify the circumvention of this obvious historical parallel. Chief Justice Hughes attempted to meet this problem by arguing: (a) "while emergency does not create power, emergency may furnish the occasion for the exercise of power' (290 U.S. 426); (b) the government must possess “. . . reasonable means to safe- 
guard the economic structure upon which the good of all depends' "(290 U.S. 422); and (c) the basic integrity of the contractual relationship was not impaired by the statute (U.S. 290 U.S. 430). Hughes set out five criteria for determining when, as in this case, a contract is not impaired but rather a valid change in the enforcement remedy. They included: (1) An emergency must exist to furnish the proper occasion for the exercise of the reserved power of the state to protect its vital interests. (2) The legislation must be addressed to a legitimate end. It must not be promulgated for the advantage of particular individuals or groups but must be for the protection of the fundamental interest of society. (3) The relief afforded must be appropriate to the emergency and granted only upon reasonable conditions. (4) The basic integrity of the contractual agreement is not impaired. And, (5) the legislation is temporary in its operation (290 U.S. 444-448). The conservative minority, later dubbed by New Dealers as the Four Horsemen of Reaction, (Rodell 1955, 217) complained bitterly that an emergency cannot alter the absolute language of the contract clause. They feared ". . . ever-advancing encroachments upon the sanctity of private and public contracts ' '(290 U.S. 448). History does not record a wholesale attack upon vested property rights. However, the decision in the Minnesota Moratorium Case did foreshadow a forty-three year dormancy of the contract clause as a substantial defense for property interests.

With the Court's decision in City of El Paso v. Simmons (379 U.S. 497 [1965]), the contract clause finally appears relegated to second class status and of interest only to the most dedicated antiquarians. In 1910, the state of Texas established a program to raise revenues through the sale of public lands to private parties. The contracts provided for a small down payment plus annual interest and principal payments. If forfeiture of the land took place by virtue of nonpayment of interest and if rights of third parties did not intervene, the law allowed reinstatement of the purchasers' title upon payment. The period for reinstatement was indeterminate. However, by 1941 it became clear to Texas legislators that the indeterminate period for reinstatement was operating as a disadvantage to the state. The perpetual reinstatement feature of the 1910 law caused considerable litigation between forfeiting purchasers and the state, and between private parties. Also, the timeless reinstatement provision prevented the state from capitalizing on the mineral wealth within the lands; the discovery of oil and gas increased land values considerably. In 1941 the 1910 law was amended to limit the reinstatement right to five years from the forfeiture date. Simmons' land was forfeited in 1947. He then took quitclaim deeds to the land, filed for reinstatement and more than five years later tendered 
payment. Because the 1941 law limited reinstatement to five years, Simmons' application for reinstatement was denied. The state then sold the land in question to the city of El Paso and Simmons filed suit to determine title. The District Court found in favor of El Paso, but the Court of Appeals reversed the District Court holding that the 1941 law impaired the obligation of the contract.

Balancing the state interests against those of the individual and building upon the Minnesota Moratorium precedent, the Warren Court found easily in favor of the state. Reversing the Court of Appeals, Mr. Justice White writing for the 8-1 majority held that the five year limitation was not a constitutionally prohibited impairment of contract. He advised: " It is not every modification of a contractual promise that impairs the obligation of contract under federal law, any more than it is every alteration of existing remedies that violates the Contract Clause"' (379 U.S. 606-507). Employing dicta found in Blaisdell, White placed the issues within a balancing of interests mode of constitutional interpretation. Quoting Chief Justice Hughes, White justified the balancing test with the words: "The decision "put it beyond question that the prohibition is not an absolute one and is not to be read with literal exactness like a mathematical formula ..."'(379 U.S.508). Portending the outcome of the balancing test, White additionally noted a long line of cases upholding the reserved power of the states in the regulation of economic matters (379 U.S. 509).

When balancing interests, the Court must consider the reasonableness of the legislation, being aware of how the outcome of the case will affect the vital interests of the parties. Predictably, the Court found in El Paso that the five year limitation on reinstatement was "... hardly burdensome to the purchaser who wanted to adhere to his contract of purchase, but nonetheless an important one to the State's interest' (379 U.S. 516-517). Yet, as Mr. Justice Black correctly pointed out in his dissent, Hughes did not balance the interests in Blaisdell. The decision "... simply held that a State could constitutionally pass a law extending the period of redemption ui a mortgage for two years where it provided for compensation to the mortgage for the resulting delay in enforcement" (379 U.S. 524). Black's point is well taken. The integrity of the contractusl relationship among the parties was not destroyed by the moratorium law; the remedy was altered in a temporary fashion. Apparently, while the El Paso decision is consistent with results in Blaisdell, the reasoning processes are substantially different.

Justice Black's dissent is a particularly instructive example of a judicial absolutist criticizing the interest balancing approach. He was probably 
correct in asserting that the majority was " . . . deciding for itself which result in a particular case seems in the circumstances the more acceptable governmental policy and then stating the facts in such a way that the considerations in the balance lead to the result "'(379 U.S. 533). Yet in fairness the absolutist approach, so characteristic of nineteenth century contract clause interpretation, was and is just as policy oriented as the interest balancing interpretative mode. The Marshall Court made law when it discovered from general principles that public grants and corporate charters are contracts. Absolutists mask their policy preferences with claims of judicial neutrality, namely, judges only find the law they do not make it. They frame the issues in apolitical terms such as rights, duties, privileges and immunities. On the other hand, the interest balancers frame issues in terms of competing interests - thereby explicitly recognizing the political character of judicial decisionmaking (Ducat 1978, 116-130). Constitutional law and politics are inseparable, by their nature judicial opinions are policy statements.

\section{The Resurgence of the Contract Clause and the Burger Court}

Though it was widely believed that the contract clause was finally a dead letter in constitutional jurisprudence, the results in United States Trust Company of New York v. New Jersey (431 U.S. 1 [1977]) and Allied Structural Steel Company v. Spannaus (438 U.S. 234 [1978]) might have been anticipated. With its opinions in these cases, the Burger Court resurrected the contract clause as a part of the living constitution. Paradoxically, the first sign of its rebirth are found in what was believed its last rites in El Paso v. Simmons. Justice Black perceptively pointed out that, given the balancing of interests approach, the understanding of the facts of a case is conditioned by the Court's view of what is good public policy. In both United States Trust and Allied Structural Steel the majority and minority disagreed fundamentally on what the facts were, which facts were relevant, and how the competing claims should have been weighed.

The facts in United States Trust Company of New York v. New Jersey are as follows. To coordinate commerce facilities in the Port of New York, the states of New York and New Jersey in 1921 entered into an interstate compact with the obligatory consent of Congress. Later, in 1962, both states passed legislation authorizing Port Authority involvement in a construction project and railroad acquisition. The legislation provided that so long as any of the bonds used to raise revenue for the project remained outstanding and unpaid and the bondholders fail to give 
their consent, New York, New Jersey or the Port Authority itself could not use any revenues or reserves pledged as security for the bonds. But by the early 1970 s it became clear that public policy goals of mass transit, pollution control and energy conservation required that the Authority increase its role in mass transportation. This was to be accomplished by building rail links to several area airports under the auspices of the Authority; yet, this was not economically feasible given the terms of a 1962 covenant. In 1973 both states passed legislation effectively repealing the 1962 covenant and did so explicitly in 1974. Bondholders, including the United State Trust Company of New York, brought suit challenging the constitutionality of New Jersey's repealing law. A New Jersey court found that the statutory repeal was a reasonable exercise of state police power and did not violate the contract clause provision of the U.S. Constitution. The New Jersey Supreme Court affirmed the lower court decision.

The Supreme Court majority, lead in this instance by Mr. Justice Blackmun, first determined there was an impairment of contract (431 U.S. 19). But then arguing consistent with the dicta in Blaisdell and the ratio in El Paso, the majority found that a "technical impairment is merely a preliminary step in resolving the more difficult question whether that impairment is permitted under the Constitution "'(431 U.S. 21). Blackmun then found that the 1973 repeal statute was neither necessary nor reasonable. He conceded that New Jersey faced serious environmental, energy, and transportation problems, and that the 1962 covenant was an impediment to their solution. However, the Court concluded there were alternative methods of financing public transportation and therefore the repeal of the covenant was not necessary (431 U.S. 29-31). Because environmental and energy problems could have been anticipated in 1962 when the covenant was entered into, the repeal statute was deemed unreasonable (431 U.S. 32). Arguing that the principle of judicial self-restraint necessitated Court deference to state legislative policy judgments (431 U.S. 33, 61-62) the minority concluded that the facts supported the contrary conclusion, namely, that the repealing statute was both necessary and reasonable as a valid exercise of state policy power (431 U.S. 38-41).

The subjective nature of the balancing test is illustrated once again in the 1978 U.S. Supreme Court case of Allied Structural Steel v. Spannaus(438 U.S. 234). The company which had an operation in the state of Minnesota, established a pension plan for its employees in 1963. Vesting of pension rights could occur if certain requirements regarding length of service and age were met. The company was the sole contributor to the 
pension fund and it alone could amend, terminate, and distribute the assets of the pension fund. Under the plan, the company was not required to make specific contributions and there were no sanctions if the company failed to make adequate contributions to this fund. In 1974 the Minnesota legislature enacted a law which subjected employers to a pension funding charge when they terminated their pension plan or when they closed their main or branch office in that state. Later, this steel company removed its branch operation from Minnesota, and the state charged it a pension funding charge of $\$ 185,000$. Claiming a contract clause violation, Allied Structural Steel filed for injunctive and declaratory relief. A federal district court upheld the 1974 Minnesota statute. The plaintiff then appealed the decision to the U.S. Supreme Court which reversed the decision of the lower court.

Written by Mr. Justice Stewart, the majority opinion stressed that a severe contractual impairment took place and the presumption of the necessity and reasonableness of the statute could not be met. It found that the state law retroactively modified "... the compensation that the company had agreed to pay its employees from 1963 to 1974 ..." and it " ... did so by changing the company's obligations in an area where the element of reliance was vital-funding of a pension plan '(438 U.S. 246). The minority view, as expressed by Mr. Justice Brennan, took the contrary position. The Act, he wrote, “. . . does not abrogate or dilute any obligation due a party to a private contract; rather, like all positive social legislation, the Act imposes new, additional obligations on a particular class of persons "'(438 U.S. 251). Thus on the issue of whether there was an impairment of a contractual obligation, the Court was not united on the fundamental threshold query.

Satisfied that the required condition of a severe impairment of contract had been met, the Court majority then concluded, consistent with the test in United States Trust Company, that the 1974 Minnesota law was neither necessary nor reasonable. It found that this state statute, first, was not enacted to protect a broad societal interest (438 U.S. 248-249). Second, it operated in a subject area never before regulated by the state (438 U.S. 250). Third, it did not involve a temporary alteration of contractual relationships but " ... worked a severe, permanent and immediate change in those relationships-irrevocably and retroactively "(438 U.S. 250). Finally, the statute was aimed not at every Minnesota employer who left the state but only those few who had in the ". . past been sufficiently enlightened as voluntarily to agree to establish pension plans for their employees" (438 U.S. 250). Disagreeing once again, Mr. Justice Brennan 
argued that the Act was designed to remedy a serious social problem (438 U.S. 251-254) and it only came into play when a plant closed and therefore the effects of the legislation were not 'sudden and unanticipated' as reported by the Court's majority (438 U.S. 254).

The ends prospective nature of the balancing test, as explained by $\mathrm{Mr}$. Justice Black in his El Paso dissent, is clear in both contemporary cases. In the 1977 U.S. Supreme Court case, the majority determined that the New Jersey repeal of the 1962 statute was neither necessary nor reasonable. The minority came to the contrary conclusion. Similarly in the 1978 case, the majority was preoccupied with the severity of the contractual impairment between Allied Structural Steel and its employees. The minority denied that any impairment took place. Both sides perceived and weighed the interests differently. It makes a crucial difference who interprets the facts and how the interests are balanced. Moreover, the Burger Court moved beyond the more simplistic balancing of interests approach found in the El Paso case. Instead of extending what had become the normal judicial deference to state legislation, the Court applied a more exacting standard. With the requirement that the state demonstrate that its action is both reasonable and necessary, it would appear that the burden of proof has shifted to the state.

Since Justices Stewart and Powell did not participate in the United States Trust Company case, the slim four-to-three majority holding for property over state interests might be interpreted as not definitive; a Court with all participating might hold otherwise. Yet with all but one member participating in the 1978 Allied Structural Steel case, the majority was even greater with a five-to-three victory for property and against state power.

Explaining the divisions within the Burger Court in New York Trust and Allied Structural Steel requires a broader political approach than legal case analysis alone can provide. Ideological factors must be understood as well. An analysis of the first six columns of Table 1 reveals that in these two cases the liberal state-oriented minority was composed entirely of Democrats. All the justices voting with the majority were Republicans, except one. Justice Powell, who did not participate in the 1977 decision but voted with the majority in the 1978 case, is a Democrat. However, Powell is a Southern Democrat, a past president of what was at the time the economically conservative American Bar Association (Melone 1977, 1983, 1987) and appointed to the Court by a conservative Republican President, Richard Nixon. This does not mean that merely knowing party affiliation, interest group loyalties, or appointing president can accurately 
predict judicial voting behavior. Indeed, this history of contract clause interpretation illustrates many other pertinent factors which need to be considered when attempting to explain judicial votes. There are too many exceptions which render these variables less than completely satisfactory predictors (Murphy and Tanenhaus 1972, 106-109; Hensely 1985). However, party affiliation and appointing president variables are linked to ideological predispositions ( Tate 1981; Ulmer 1973; Carp and Rowland 1983; Ulmer 1986). In the United States Trust Company and Allied Structural Steel cases these factors are illuminating.

Since the New Deal, Democrats appointed to the Court have usually been sensitive to claims of government's authority to regulate the economy and to protect community well-being. An exception has been the Democrat Mr. Justice Black, whose dissenting opinion in El Paso v. Simmons may be explained by his absolutism. Largely constrained by the institutional norm of judicial self-restraint, even Republicans appointed in the two decades after the end of the New Deal era have been reluctant to contradict state authority. Except for Republican Stewart, who was appointed in 1958, the remaining four Republicans on the Burger Court were appointed by modern conservative Republican Presidents, Nixon and Ford. It is not surprising, then, that four Republicans appointed by Presidents Nixon and Ford, joined by an older vintage Republican and a Democrat both appointed by a Republican President would unite to balance the interests in favor of private property against state power.

This suggests that conservative versus liberal ideologies, reflected in the surrogate indicator of party affiliation and or appointing president, may in a crude sense aid in explaining and predicting future Supreme Court treatment of contract clause cases. Confidence in this conclusion is buttressed by a published study reporting scale scores for the Burger Court between 1975-1980 (Dudley and Ducat 1986). These scores reproduced in the fourth column of Table 1 are based on 232 economic cases of which 54 percent were by a divided Court. The cases include not only contract clause cases but ones involving a wide range of constitutional disputes between unions and employers, challenges to government regulation of corporations, and so on. A negative sign indicates a conservative ideological position, and a plus sign is a liberal position. Perfect conservatism or liberalism is 1.0, depending on the direction sign. Rehnquist, Burger and Powell display the most conservative voting records. Stevens is slightly conservative, and Blackmun's behavior is barely left of center. White is slightly more liberal than Blackmun, and Marshall and Brennan exhibit the most liberal record. The close relationship between the justices 


\section{Table 1}

Burger Court Party and Appointing President Background

Characteristics, Economic Ideology Scale Scores, and Contract Clause Votes

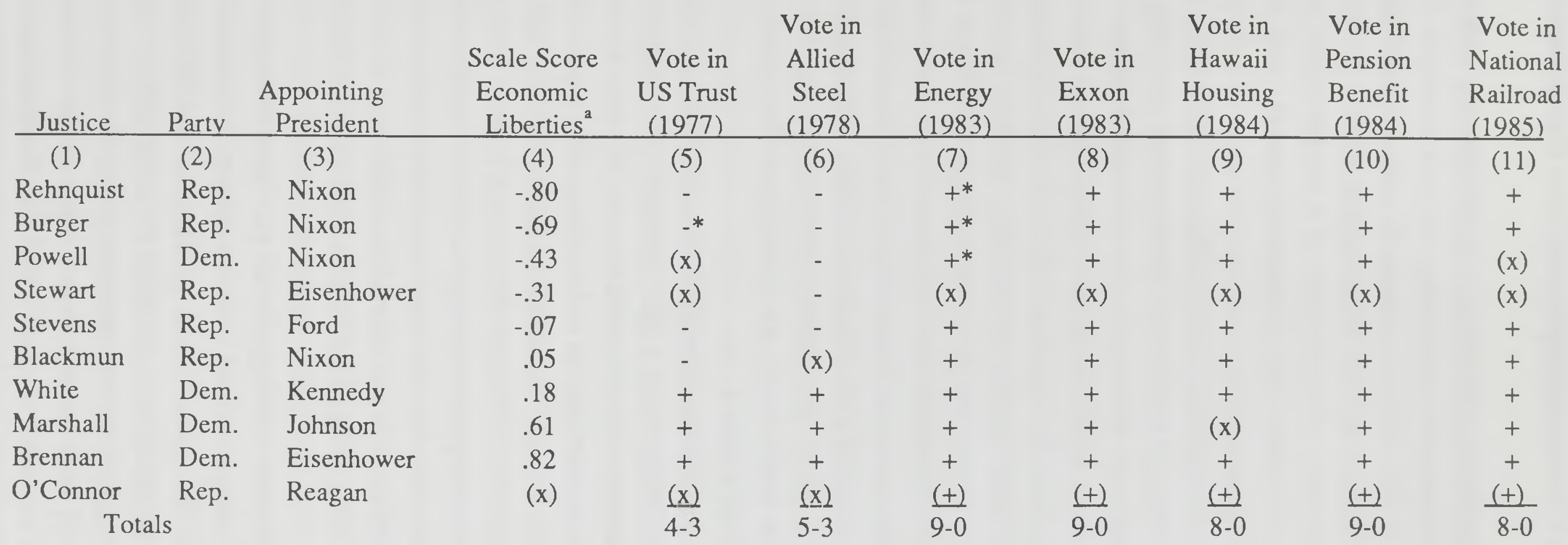

(1) Minus vote for private property

$(+)$ Positive vote for state power

$\left({ }^{*}\right)$ Concurring opinion

(x) Not Participating

${ }^{a}$ scores obtained from Dudley and Ducat,

"The Burger Court and Economic Liberalism,"

The Western Political Quarterly 39 (June 1986): 243. Table 5. 
party affiliations, appointing presidents, scale scores, and votes in the 1977 and 1978 decisions is unmistakable.

Based on the 1977 and 1978 decisions it was reported widely (Hurst 1978; Clark 1978; Mctamaney 1977; Schwartz 1980 ) that necromantic experiences to the contrary, the presence of John Marshall is once again felt within the Marble Palace. The contract clause is back as a constitutional weapon against state power.

However, the judicial process all too often will defy easy explanation. Because of legal norms, judicial role perceptions, and the plethora of possible fact situations, a formula such as values times facts equals decisions will not suffice as an adequate explanation of judicial decisionmaking. This is as true as the mechanical view of jurisprudence is false; i.e., that rules times facts equals decisions. Do not conclude that the Court's balancing test leaves the justices without restraints; they possess leeway, not license. It is possible for the Court to reach a decision in favor of state power over property interests despite the justices' apparent value preferences. A case in point is the Supreme Court's first genuine contract clause decision since 1978, Energy Resources Group, Inc. v. Kansas Power and Light Co (103 S.Ct. 67 [1983]). The justices votes are recorded in column 7 of Table 1 .

A private energy company, Energy Resources Group, claimed that a state agency, Kansas Power and Light Company, violated the contract clause when in a series of complicated events, Kansas Power and Light failed to abide by an agreement to redetermine the price of natural gas. Because of this failure, Energy Resources believed that it had a legal right to terminate its contract with Kansas Power and Light. The public utility counterclaimed with the argument that it need not redetermine the prices of natural gas because subsequent state legislation promulgated under a federal law imposed price controls on old gas contracts as well as containing other pertinent changes in the relationship between the producer and itself.

Mr. Justice Blackmun writing for a six person majority used the opportunity to clarify the standard first articulated in United States Trust Company and Allied Structural Steel. Citing Allied, Blackmun emphasized that the threshold question is whether the state statute has operated as a substantial impairment of a contractual relationship. If the impairment is great, then the level of judicial scrutiny is also great. On this point, the nine justices (the six member majority and the three concurring justices) were in singular agreement. Because the industry itself is one which is heavily regulated to begin with, and although when the original contracts 
to deliver natural gas to the state power company were consummated the state did not regulate natural gas prices, the industry was nonetheless under extensive state supervision and intrusion. Therefore, although there may have been an impairment of the contractual obligation, the impairment was not substantial.

In what the three concurring justices (Powell, Burger, and Rehnquist) properly regarded as dicta, Mr. Justice Blackmun went on to address two additional requirements for finding a contract clause violation. Once again, he found no violation of the constitutional standards.

The first standard asks the extent to which the state statute in question "... is prompted by significant and legitimate state interests" (103 S.Ct. 708). The majority answered that of course the state in the exercise of its police power may protect consumers from escalating natural gas prices owing to the federal deregulation. Satisfied that the state had a legitimate public purpose the Court's spokesman then asked whether " . . . the adjustment of the rights and responsibilities of contracting parties is based upon reasonable conditions and is of a character appropriate to the public purpose justifying the legislation's adoption "'(103 S.Ct. 705). Once again Mr. Justice Blackmun found that the state action was appropriate. The Kansas act was limited in nature and reasonably limited the price of intrastate gas that otherwise would have escalated to unacceptable heights. Blackmun also pointed out that the act in question was temporary in nature, and he concluded in a judicial self-restraint vein that the Court should defer to legislative judgments when it is reasonable to do so. This case was, in his opinion, such an instance.

Note that the Court is apparently united on the answer to the threshold question. There is no severe impairment of the contractual obligation. Both the dominant majority which favored private property over state power in the 1977 and 1978 cases, and the liberal minority in those cases agree on this major point; or it seems they agree. The reason for caution is the knowledge that Justices Brennan, Marshall and White did not agree with the conservative majority that a significant impairment took place in all three of the contemporary cases beginning with New York Trust, continuing with Allied and ending with Energy. It is somewhat problematical whether all the justices share the same cognitive attitude of what constitutes a constitutionally prohibited contractual impairment. On the other hand, what might be the worst fear of state power oriented liberals has not been realized.

Since the 1983 Energy case, the Court has in four different written opinions refused to extend contract clause protections further. All at- 
tempts by private parties to limit governmental power by alleging contract clause violations have been rejected. Columns 8-11 of Table 1 bear this out.

In Exxon Corp. v. Eagerton (103 S.Ct. 2296 [1983]), a case argued and decided just a few months after Energy, the Supreme Court considered an Alabama statute which increased the severance tax on oil and gas extracted from wells within the state. The statute exempted royalty owners from the tax, and was designed to protect consumers from pass-through cost increases in retail prices imposed by producers because of the tax.

The Exxon Corporation challenged the statute under the Constitution's supremacy, equal protection, and contract clauses. Writing for a unanimous Court, Mr. Justice Thurgood Marshall concluded that the passthrough prohibition on the sale of gas in interstate commerce was preempted by federal law. However, the state may apply the prohibition to the sale of intrastate gas (103 S.Ct. 2303). The Court rejected the equal protection claim because the regulation need only meet the constitutional standard of rationality, and not the higher one required when fundamental interests and suspect classifications are involved (103 S. Ct. 2308).

The Court found no contract clause violation because the litigated statute: (a) did not nullify contractual obligations of which Exxon was a beneficiary; and (b) the pass-through provision imposed a generally applicable rule of conduct designed to protect consumers. According to the Court, the effect of this statutory provision on then existing contracts was incidental (103 S.Ct. 2305).

Mr. Marshall seized the moment to reaffirm state prerogatives. He went so far as to cite the two seminal landmark decisions which affirmed the use of state power most clearly: Stone v. Mississippi (1880) and Home Building and Loan Association v. Blaisdell (1934). His point is simple. The contract clause must not be read to deprive states of their broad regulatory powers in the economic realm (103 S.Ct. 2305,2306).

At the next term of the Court, an attempt to use the contract clause as a limitation on the eminent domain power was dismissed in a single footnote. The dispute, Hawaii Housing Authority v. Midkiff (104 S.Ct. 2321 [1984]), arose out of a state land reform statute. Writing for a unanimous Court Justice Sandra Day O'Connor, a Republican appointed by a Republican President, pointed out that the contract clause had never been used against the exercise of eminent domain power (104 S.Ct. 2330, note 6).

In another case that same year, Pension Benefit Guaranty Corp. v. R.A. Gray \& Co. (104 S.Ct. 1709 [1984]), the Court rejected the suggestion that the constitutional principles developed in Energy and Allied Structural 
Steel be applied to due process litigation. Mr. Brennan writing for a once again unanimous bench stated that the Court "never held ... that the principles embodied in the Fifth Amendment's Due Process Clause are coextensive with prohibitions existing against state impairments of preexisting contracts"' (104 S.Ct. 2720).

With the last contract clause case the Burger Court would decide, we are assured that despite the 1977 and 1978 setbacks for state power, a nineteenth century style revival of property rights over governmental power is unlikely. In National Railroad Passenger Corp. v. Atchison Topeka and Santa Fe (105 S.Ct. 1441 [1985]), private railroad companies brought suit against Amtrak. They challenged the constitutionality of a congressional enactment requiring railroads to reimburse Amtrak for employee pass privileges. Fifth Amendment due process and contract clause claims were rejected by a unanimous Court.

In terms of the specific contract clause argument, the railroads attempted to link the facts of its case with those found in New York Trust. Once again, the Court resisted the suggestion to use the contract clause as a further limitation upon governmental power.

Unlike the covenants between New York Trust and the state of New Jersey, the United States government never entered into an agreement with anyone to do anything. The United States expressly reserved to itself the right to revoke or repeal the original act which the railroads argue bind the Congress contractually to them (105 S.Ct. 1457). Moreover, Congress did not impair a private contractual right. As a result, Mr. Justice Marshall writing for the Court concluded that he felt no obligation to consider whether the alleged impairment is substantial (105 S.Ct. 1457).

In summary, the Burger Court chose not to extend the resurrection of the contract clause beyond the narrow facts in New York Trust, and Allied Structural Steel. It is also clear that the Court remained committed to the rules as articulated in its 1977 and 1978 decisions, and reaffirmed in the 1983 Energy decision. A wholesale attack on the exercise of governmental power to regulate economic affairs is not armed with a multi-headed and targeted weapon. Instead, the clause is limited to actual contractual rights or obligations. If an impairment of contract is found, the court must then determine whether the impairment is substantial. If not, the cause is without merit. When a substantial impairment is found, then the government action may be deemed constitutionally infirm if the law in question is neither necessary nor reasonable. This conclusion is confirmed in each of the last four cases to come before the Burger Court. Since the Energy decision, all the participating justices agreed not to extend the clause 
beyond what might be narrowly deduced from United States Trust Company (1977), and Allied Structural Steel (1978), despite divergent ideologies, political backgrounds, or appointing presidents. Opting not to radically alter the relationship of state government with private business, the Supreme Court as an institution restrained itself.

\section{Conclusion}

This analysis of the history of the contract clause serves to illustrate the wisdom of continuing to view judicial decisionmaking from a political perspective. The contract clause cannot be understood by studying the words of the constitution alone. This study reinforces Martin Shapiro's (1981, 63) observation, " . . . courts tend to be loaded with multiple political functions, ranging under various circumstances from bolstering the legitimacy of the political regime to allocating scarce economic resources or setting major social policies." Because jurists exercise discretion, there is need for more than textual analysis of their formal written judicial opinions. Interest group politics, ideological attitudes, social backgrounds, role perceptions, and small group dynamics are also pertinent explanatory variables. Placing judicial opinions in their broader socioeconomic and historical context also enriches understanding. Lastly, recognizing that the Supreme Court is an uncommon although not a functionally unique institution with a life of its own completes an otherwise unbounded picture of judicial events.

A fair reading of the history of the contract clause points to the conclusion that the Framers' intentions are sometimes difficult to ascertain with precision. Depending upon one's ideological perspective, what one believes known about intent is not always accepted by others (Melone and Mace 1988, 146-147). The point is what the Framers really intended is subject to different interpretations by persons with different backgrounds and attitudes. Moreover, social and economic conditions may require looking beyond the late eighteen century for guidance. The judicial absolutism of John Marshall in favor of private property gave way to the right of the people to protect themselves from the excesses of private power. Moreover, the balancing of interests approach to contract clause jurisprudence made it possible for jurists to weigh the equities in individual cases.

Though by the mid-1960s it was widely assumed that the contract clause would no longer serve to check state power, the Burger Court saw fit to revive it. This came about because of a conservative majority. It was 
a division on the Court reflecting the justices' partisan backgrounds, appointing presidents' political party, and the justices' ideologies as marked by their scores on an economic liberties scale. Though the proprivate property oriented justices were in control, attempts by private property litigants to expand the Court's contract clause revival beyond the 1977 and 1978 decisions all failed during the remainder of the Burger era. The Court was unanimous in its refusal to make the contract clause a legal vehicle for turning back government regulation of economic life.

However, the subjective nature of the balancing test grants to all judges a power to curb the power of the fifty states. Skillful minds may employ the precedents of United States Trust, and Allied Structural Steel to the advantage of the state vis-a-vis property interests or the opposite. The balancing test is, after all, a two-edged sword; the Supreme Court's own holding in the Energy case and beyond proves the point.

Given this situation, some may fault the Burger Court, especially when comparing it to the absolutist oriented courts of an earlier age. A balancing of interests approach does not provide clear sets of legal norms as rule oriented types of an absolutist persuasion might like. However, such a view fails to appreciate the political nature and institutional setting of courts. The legal system is more than a system of interrelated rules. It is also a process by which competing interests are adjusted and accommodated. It is also true that the Supreme Court has a life of its own. As an institution, it is restrained by its past decisions and the relationships it produces among other political actors and between itself and others. The constant testing and readjustment of legal rules and principles in response to individual and group demands contribute to general system stability. No doubt, such activity is lamented by those who seek certainty from the judicial system. Politics, however, is not simply a matter of winning and losing. The interests of third parties, including those of the regime in which judicial actors are subsystem players and of society more generally are important factors in the decisionmaking mix. Of course, judges make law; the history of the contract clause confirms the proposition. Lastly, judicial behavior and judicial politics take place within a complex institutional setting. The institution creates, alters and modifies the boundaries of political conflict. C. Herman Pritchett put it well: " it is judging in a political context, but it is still judging; and judging is something different from legislating and administering"' $(1969,42)$. 


\section{Notes}

${ }^{1}$ This is a revised version of a paper first presented at the 1987 Convention of the Western Political Science Association, Anaheim, Calif., March 26-28, 1987. The author wishes to acknowledge Professor Richard Dale for his criticisms of a much earlier draft of this article and Scott Myers, Research Assistant, Department of Political Science, Southern Illinois University, for his helpful comments on the final manuscript.

${ }^{2}$ It is known that in an early state case later cited by the Supreme Court in several contract clause decisions, the ex post facto prohibition was argued by legal counsel. See: Wright 1938, 20-21.

3 Wallace Mendelson (1985) argues that the Framers must have intended to include public contracts as well as private contracts as part of the meaning of the contract clause. I think he is wrong (Melone, 1988; Menselson, 1988).

\section{References}

Beard, Charles A. 1913. An Economic Interpretation of the Constitution of the United States. New York: The Macmillan Company.

Carp, Robert A. and Rowland, C.K. 1983. Policy-Making and Politics in the Federal District Courts. Knoxville, TN: The University of Tennessee Press.

Clark, Jeffery L. 1978. The Contract Clause Reemerges: New Attitude Toward Judicial Scrutiny of Economic Legislation. Southern Illinois University Law Journal 1978: 258-277.

Ducat, Craig R. 1978. Modes of Constitutional Interpretation. St. Paul: West Publishing Co.

Dudley, Robert L. and Ducat, Craig R. 1986. The Burger Court and Economic Liberalism. The Western Political Quarterly 39: 1236-249.

Farrand, Max, ed. 1937. The Records of the Federal Convention of 1787.4 vols. New Haven: Yale University Press.

Hensely, Thomas R. 1985. A Critique of Personal Attribute Theory: An Analysis of C. Neal Tate's Personal Attribute Models of the Voting Behavior of U.S. Supreme Court Justices or 'It May Have Something to Do With My Childhood'. Chicago, IL: Paper Prepared for Delivery at the Annual Meeting of the Midwest Political Science Association, April 18-20, 1985.

Hurst, Thomas R. 1978. Municipal Bonds and the Contract Clause: Looking Beyond the United States Trust Company v. New Jersey. Hastings Constitutional Law Quarterly 5: 25-59. Johnston, Richard E. and Thompson, John T. 1980. The Burger Court and Federalism: A Revolution in 1976? The Western Political Quarterly 33: 197-216.

Magrath, Peter c. 1966. Yazoo: The Case of Fletcher v.Peck. New York: W.W. Norton and Company.

March, James G., and Johan P. Olsen. 1984. The New Institutionalism: Organizational Factors in Political Life. American Political Science Review 78: 734-49.

Mctamaney, Robert A. 1977. United States Trust Company of New York v. New Jersey: The Contract Clause in a Complex Society. Fordham Law Review 46: $1-56$.

Melone, Albert P. 1977/1979. Lawyers, Public Policy and Interest Group Politics. Washington, D.C.: University Press of America. 
Melone, Albert P. 1983. The American Bar Association, Antitrust Legislation and Interest Group Coalitions. Policy Studies Journal 1: 684-698.

Melone, Albert P. 1987. Bar Associations in. The Encyclopedia of the American Judicial System, ed. Robert Janosik. New York: Scribner's.

Melone, Albert P. 1988. Mendelson v. Wright: Understanding the Contract Clause. The Western Political Quarterly 41: 791-199.

Melone, Albert P. and George Mace, 1988. Judicial Review and American Democracy. Ames: Iowa State Univerwity Press.

Mendelson, Wallace. 1985. B.F. Wright on the Contract Clause: A Progressive Misreading of the Marshall-Taney Era. The Western Political Quarterly 38: 262-275.

Mendelson, Wallace, 1988. Bootstraps v. Evidence: A Response to Professor Melone The Western Political Quarterly 41: 801-805.

Murphy, Walter F. and Tanenhaus, Joseph. 1972. The Study of Public Law. New York: Random House.

Pritchett, C. Herman. 1968. The American Constitution, 2 ed. New York: McGraw-Hill Book Company.

Pritchett, C. Herman. 1969. The Development of Judicial Research. In Frontiers of Judicial Research. eds. Joel Grossman and Joseph Tanenhaus. New York: John Wiley.

Rodell, Fred. 1955. Nine Men: A Political History of the Supreme Court of the United States from 1790 to 1955. New York: Vintage Books.

Schmidhauser, John R. 1958. The Supreme Court as Final Arbiter in Federal-State Relations, 1789-1957. Chapel Hill, NC: The University of North Carolina Press.

Schwartz, Bernard. 1980. Old Wine in Old Bottles? The Renaissance of the Contract Clause. In The Supreme Court Review. Philip B. Kurland and Gerhard Casper, eds. Chicago: University of Chicago Press, 95-121.

Shapiro, Martin M. 1981. Courts: A Comparative and Political Analysis. Chicago: University of Chicago Press.

Skopol, Theda. 1984. Vision and Method in Historical Sociology. Cambridge: Cambridge University Press.

Smith, Rogers M. 1988. Political Jurisprudence, The 'New Institutionalism,' and the Future of Public Law. American Political Science Review 82: 89-108.

Stumpf, Harry P., Martin Shapiro, David J. Danelski, Austin Sarat, and David M. O'Brien. 1983. Whither Political Jurisprudence: A Symposium. The Western Pcl:iticá: Quarterly. 36: 533-569.

Tate, C. Neal. 1981. Personal Attribute Models of Voting Behavior of U.S. Supreme Court Justices: Liberalism in Civil Liberties and Economics Decisions, 19461978. American Political Science Review 75: $355-367$.

Ulmer, S. Sidney. 1973. Social Background as an Indicator of the Votes of Supreme Court Justices in Criminal Cases: 1947-1956 Terms. American Journal of Political Science 17: 622-630.

Ulmer, S. Sidney. 1986. Are Social Background Models Time-Bound? American Political Science Review 80: 957-967.

Wood, Gordon S. 1969. The Creation of the American Republic, 1776-1787. Chapel Hill: The University of North Carolina Press.

Wright, Benjamin F., Jr. 1938. The Contract Clause of the Constitution. Cambridge: Harvard University Press. 